\title{
PARA ALÉM DO COMITÊ DE ÉTICA EM PESQUISA: DESAFIOS E PERSPECTIVAS DO TRABALHO DE CAMPO DE BIOANTROPOLOGIA NA AMAZÔNIA BRASILEIRA FRENTE À DOENÇA FALCIFORME
}

\author{
Ariana Kelly Leandra Silva da Silva $ه$ \\ Secretaria de Estado de Educação do Pará \\ Universidade do Estado do Pará \\ Roseane Bittencourt Tavares Oliveira (D) $\triangle$ \\ Lígia Amaral Filgueiras (ID $ه$ \\ Secretaria de Estado de Educação do Par
Universidade do Estado do Pará \\ Laércio Moreira Cardoso-Júnior (1)
}


O artigo relata uma experiência de caso sobre estudos de Bioantropologia em um contexto de saúde hematológica, indicando os principais desafios e perspectivas do trabalho de campo durante os cursos de Mestrado/Doutorado com concentração em Bioantropologia na Universidade Federal do Pará (UFPA). Descrevemos o step by step da imersão em campo em um hemocentro de Belém (PA) em contato com pessoas com doença falciforme, apresentando o métier da Bioantropologia com os diversos percursos éticos/bioéticos da área em questão. Realizamos pesquisa qualitativa em saúde com 60 pessoas com diagnóstico da forma mais grave da doença falciforme, a anemia falciforme (AF ou Hb SS), com um total de 120 entrevistas em duas fases via Termo de Consentimento Livre e Esclarecido (TCLE) com o intuito de levantar dados sobre ancestralidade genética com teste de DNA autossômico, identidade étnico-racial e aspectos socioeconômicos, utilizando a técnica da observação participante e extensa revisão bibliográfica. Os resultados demonstraram que o grupo pesquisado tem maior frequência de DNA europeu $(58,2 \%)$ e enfrenta obstáculos ligados à pobreza e ao racismo, sendo que a análise bioantropológica é interdisciplinar nas ciências humanas e afins, exercitando amplamente o caráter ético/bioético da pesquisa sociocultural no contexto amazônico.

Palavras-chave: Bioética; Bioantropologia; Doença Falciforme.

\section{BEYOND THE RESEARCH ETHICS COMMITTEE: CHALLENGES AND PERSPECTIVES OF BIOANTHROPOLOGY FIELDWORK IN THE BRAZILIAN AMAZON IN THE FACE OF SICKLE CELL DISEASE}

The article reports a case study on Bioanthropology studies in a hematological health context, indicating the main challenges and perspectives of fieldwork during the Masters/ Doctorate courses with a concentration in Bioanthropology (Federal University of Pará/UFPA). We describe the step by step of immersion in the field in a blood center in Belém/PA in contact with people with sickle cell disease, presenting the Bioanthropology metier with the different ethical/bioethical paths of the area in question. We conducted qualitative health research with 60 people diagnosed with the most severe form of Sickle Cell Disease, Sickle Cell Anemia (SCA or $\mathrm{Hb} \mathrm{SS}$ ), with a total of 120 interviews in two phases via the Informed Consent Form (ICF) in order to collect data on genetic ancestry with autosomal DNA testing, ethnic-racial identity and socioeconomic aspects, using the technique of participant observation and extensive bibliographic review. The results showed that the researched group has a higher frequency of European DNA (58.2\%), faces obstacles linked to poverty and racism and that the bioanthropological analysis is interdisciplinary in the humanities and related sciences, largely exercising the ethical / bioethical character of the research socio-cultural context in the Amazon.

Keywords: Bioethics; Bioanthropology; Sickle Cell Disease.

\section{AU-DELA DU COMITE D'ÉTHIQUE DE LA RECHERCHE: DEFIS ET PERSPECTIVES DU TRAVAIL DE TERRAIN EN BIOANTHROPOLOGIE EN AMAZONIE BRESILIENNE FACE A LA DREPANOCYTOSE RESUMEN}

L'article rapporte une étude de cas sur les études de bioanthropologie dans un contexte de santé hématologique, indiquant les principaux défis et perspectives du travail de terrain lors des cours de maîtrise/doctorat avec une concentration en bioanthropologie (Universidade Federal do Pará/UFPA). Nous décrivons pas à pas l'immersion sur le terrain dans un centre de transfusion sanguine à Belém/PA en contact avec des personnes atteintes de drépanocytose, présentant le métier de Bioanthropologie avec les différents parcours éthiques/bioéthiques de la zone en question. Nous avons mené une recherche qualitative en santé auprès de 60 personnes diagnostiquées avec la forme la plus sévère de drépanocytose (Hb SS), avec un total de 120 entretiens en deux phases via le formulaire de consentement éclairé (ICF) afin de recueillir des données sur l'ascendance génétique avec des tests $\mathrm{ADN}$ autosomiques, l'identité ethnique et raciale et les aspects socio-économiques, en utilisant la technique de l'observation participante et une revue bibliographique approfondie. Les résultats ont démontré que le groupe étudié a une fréquence plus élevée d'ADN européen (58,2\%), fait face à des obstacles liés à la pauvreté et au racisme et que l'analyse bioanthropologique est interdisciplinaire dans les sciences humaines et connexes, exerçant largement la nature éthique et bioéthique de la recherche socio-contexte culturel en Amazonie.

Mots-clés: Bioéthique; Bioanthropologie; Drépanocytose. 


\section{INTRODUÇÃO}

"Sou branco de olho azul, eu não sei porquê tenho Anemia Falciforme"1. A fala racializada ${ }^{2}$ do interlocutor com Doença Falciforme ${ }^{3}$ (DF) evidencia o teor da pesquisa de campo do bioantropólogo, com características peculiares da estranheza, que é conhecer as liminaridades do Outro com uma doença genética - o nativo à la Malinowski ${ }^{4}$-, particularmente na Amazônia paraense ${ }^{5}$, numa terra entre grandes cidades urbanizadas e lugares rurais, rios e florestas, sociabilidades e relações étnicorraciais que dão o tom e o contexto de conhecer - e reconhecer - o modus operandis da observação participante no cotidiano de um hemocentro regional na cidade de Belém por pesquisadores que experimentam a realidade social de uma enfermidade crônica entre protocolos, termos de consentimentos, ética e bioética na pesquisa e vicissitudes humanas das mais diversas formas.

As análises bioantropológicas que estão na interconexão entre a biologia e a cultura, a natureza e a sociedade ou entre o natural e o social estão cada dia mais em voga na contemporaneidade, em particular, por apresentarem uma abordagem biocultural em estudos de campo na região amazônica e/ou no Brasil. O campo de atuação da Bioantropologia nos dias de hoje busca concentrar

1 O relato descreve uma das narrativas a respeito da pergunta: "Você sabe o que é Anemia Falciforme?", em entrevista realizada no hemocentro regional de Belém no ano de 2011 (Pesquisa de mestrado em Antropologia), na qual o interlocutor, Pedro (fictício), autônomo, 45 anos, morador do interior do Pará, descreve a sua perplexidade por ser branco e ter uma doença genética que ainda é vista como uma "doença de negro" em nossa sociedade.

2 De acordo com Munanga (2004: 1): "Parece simples definir quem é negro no Brasil. Mas, num país que desenvolveu o desejo de branqueamento, não é fácil apresentar uma definição de quem é negro ou não. Há pessoas negras que introjetaram o ideal de branqueamento e não se consideram como negras. Assim, a questão da identidade do negro é um processo doloroso. Os conceitos de negro e de branco têm um fundamento etno-semântico, político e ideológico, mas não um conteúdo biológico".

3 A Doença Falciforme é a doença genética mais prevalente em todo o mundo. No Brasil, cerca de 3.500 pessoas nascem anualmente com a sua forma sintomática, o grupo homozigoto ( $H b S S$ ), com uma alteração na morfologia celular das hemácias do indivíduo que, em uma situação de estresse ambiental, ficam em forma de foice ou meia-lua, daí o nome "falciforme", causando uma série de consequências fisiológicas no organismo da pessoa com a doença. Cerca de 200.000 pessoas nascem com o chamado Traço Falciforme ( $\mathrm{Hb} A S$ ), com apenas um alelo alterado, pessoas, em geral, assintomáticas. A DF tem cura por meio do Transplante de Medula Óssea (TMO) entre doadores compatíveis (Cançado 2007, Naoum 2000a e 2000b, Naoum 2011).

4 No sentido de ser uma experiência de estudo de caso em um hemocentro no qual a convivência com os interlocutores é mais imediata e mediada por um TCLE, uma prancheta, um jaleco e outros elementos diferenciados da convivência diária da observação participante vivenciada pelo autor.

5 No Pará, estima-se que a DF ocorra em cerca de $1 \%$ da população paraense para as pessoas com Anemia Falciforme ( $H b S S$ ), e em torno de 4,40\% para os indivíduos com o Traço Falciforme ( $H b A S$ ), com maior prevalência entre as pessoas "negras" e "pardas" e menor prevalência entre as pessoas "brancas" e "amarelas". Todavia, como o Teste do Pezinho (Teste de Guthrie) fora universalizado apenas em 2010, o número de subnotificações deve ser considerado provavelmente para um número maior de pessoas com a síndrome (Cardoso e Guerreiro 2010, Silva 2015, Silva 2016). 
estudos interdisciplinares que podem ser observados a partir de informações que vão desde identificações genéticas ou filogenéticas de grupos humanos do passado e do presente, pesquisas sobre determinantes sociais da saúde em comunidades tradicionais ou urbanas, escavações de fósseis ancestrais em contextos de sítios arqueológicos, levantamento de vulnerabilidades sociorraciais sobre saúde e doença e demais idiossincrasias de populações humanas diferenciadas etc., demandando uma maneira com um recorte específico de fazer pesquisa de campo (Bezerra e Silva 2009, Gaspar-Neto 2012, Silva e Silva 2013, Da-Glória e Piperata 2019, Silva et al. 2020).

O lócus de atuação dos bioantropólogos - e de antropólogos sociais, culturais, sociólogos, historiadores etc. -, em muitas situações, necessitam de "prévia autorização" de comitês, hospitais, hemocentros, carceragens, centros de saúde, escolas, repartições públicas e outros núcleos que lidam diretamente com a saúde, a doença e a vida desses indivíduos, alterando o estilo, digamos, clássico, de gerar um dado de pesquisa na Antropologia, como os estudos etnográficos com povos originários ou outros agrupamentos humanos, que são autorizados mediante o contato do ser aceito em campo utilizando a técnica do olhar, ouvir e escrever, sendo o uso de entrevistas substituído pela convivência diária com os sujeitos da pesquisa (Cardoso de Oliveira 2000, Laguardia 2002, 2006, Laplantine 2004, Fry et al. 2007, Uriarte, 2012).

A primeira dissertação específica na área de Bioantropologia em um programa de Antropologia no Brasil foi defendida em 2012 na UFPA, no Programa de Pós-Graduação em Antropologia (PPGA), criado em 2010 e, até o momento, o único curso a oferecer, de forma integrada, formação em Antropologia Social/Cultural, Arqueologia e Bioantropologia no Brasil.

Na dissertação "Doença Falciforme como experiência: as relações entre vulnerabilidade social e corpo doente enquanto fenômeno biocultural no estado do Pará” (Silva 2012) buscou-se problematizar o convívio com uma doença crônica de um grupo de 45 interlocutores acometidos pela Doença Falciforme $(H b S)$ no Pará, em especial, entre aqueles que apresentam o agravo conhecido como Anemia Falciforme ( $\mathrm{Hb}$ $S S)$, que é a hemoglobinopatia mais comum em todo o mundo. No estudo em questão, a abordagem bioantropológica se concentra na representação biossocial da doença partindo da experiência relatada pelos próprios sujeitos que convivem com a cronicidade da síndrome em seu cotidiano (Silva 2012, Silva \& Silva 2013).

Assumindo o métier do antropólogo, e diante da variedade de estudos na área em questão, 
pretende-se aqui entender como se configurou um estudo de caso dentro do trabalho de campo do bioantropólogo, especialmente na Amazônia paraense, que, dentre outras demandas, é um observador da saúde e da doença humana em consonância com aspectos biológicos, socioambientais, evolutivos e ecológicos de diferentes grupos culturais e étnicorraciais, quais sejam: ribeirinhos, quilombolas, trabalhadores rurais, interlocutores de centros urbanos ou acometidos por doenças crônico-degenerativas, a fim de descrever uma pesquisa de campo em um ambiente particular: um hemocentro regional, com relatos anteriores e posteriores à aprovação de um Comitê de Ética em Pesquisa (CEP) via Plataforma Brasil, num exercício de "se fazer entender" um campo de concentração que se abre, pretendendo ir além das divisórias acadêmicas.

A pesquisa realizada no hemocentro na cidade de Belém é analisada como o contexto de uma Aldeia, de acordo com a perspectiva malinowskiana tratada por Giumbelli (2002: 97) na qual descreve que o trabalho de campo propicia "um contato o mais íntimo possível" com os indivíduos estudados, permitindo ao pesquisador "tomar parte na vida da aldeia”, sendo que a nossa Aldeia tem como foco o ambiente do hemocentro.

Giumbelli (2002: 97) indica ainda que, de acordo com a perspectiva de Malinowski ${ }^{6}$, a etnografia clássica ou propriamente dita precisa trilhar "três caminhos", quais sejam: "a documentação estatística por evidência concreta, a atenção aos imponderáveis da vida real e a elaboração de um corpus inscriptorum". Assim sendo, a documentação estatística na Aldeia-Hemocentro é representada pelos TCLE, prontuários, os imponderáveis, as entrevistas gravadas ao longo de nove meses de pesquisa de campo, o corpus, os laudos de ancestralidade, que longe de demonstrarem relações de simples trocas por "miçangas", podem sem entendidos como a complementação do estudo de caso com pessoas com AF que foi realizada.

Para tanto, é necessário relatar sobre o surgimento dos CEP e da Bioética enquanto lugar de discussão privilegiada da ética propriamente dita, fazendo um paralelo com uma doença crônica, a Doença Falciforme na Amazônia. Posteriormente, contextualizar a AF no processo do trabalho de

6 Bronislaw Malinowski (1884-1942) foi um dos cientistas sociais mais carismáticos do século 20. Suas contribuições como o pai fundador da Antropologia Social e sua personalidade complexa lhe deram notoriedade internacional e um status quase místico. Quando tinha 36 anos de idade, já havia criado uma inexorável metodologia de campo e técnicas etnográficas que assegurariam seu legado intelectual. Malinowski teve contato com os principais pesquisadores da disciplina e no início da I Guerra Mundial viajou para sua primeira pesquisa de campo na Austrália, com vários povos, como os Mailu em 1915 e depois com os nativos da Nova Guiné, os Trobriand. Em 1922, publicou sua obra "Argonautas do Pacífico Ocidental". Outras de igual importância são "Sexo e repressão na sociedade selvagem” (1927), "A vida sexual dos selvagens" (1929) e "Jardins corais e sua magia" (1935) (Young 2004, tradução livre). 
campo bioantropológico em um hemocentro, a fim de delimitar os desafios e as perspectivas envolventes. Situar a ética, a bioética e a AF em discussões que abordem situações globais e locais é o que se pretende descrever à guisa de conclusão.

\section{ALGUNS ANTECEDENTES HISTÓRICOS DA BIOÉTICA E DOS COMITÊS DE ÉTICA EM PESQUISA NO MUNDO E NO BRASIL}

O livro "O que é Bioética”, de Diniz e Guilhem (2008), engloba três grandes abordagens da Bioética: a Historicista, com eventos pontuais do passado, como os campos nazistas, as guerras mundiais e os tratados de direitos humanos, que contribuíram para as inúmeras discussões éticas que envolvem a dignidade da pessoa; a Filosófica, que aborda a história da Filosofia da Moral, exigindo certo domínio da História da Filosofia, lugar que tratava sobre assuntos morais, éticos e filosóficos profundos; e a Temática, que discute um grande número de casos e conjunturas de temas da vida, além de dilemas peculiares.

O foco da obra em questão é redirecionar a trajetória da bioética no Brasil a partir de teorias e críticas com o intuito de refletir sobre os conflitos morais que a regem, aglutinando tópicos desde o seu nascimento, isto é, quais os principais acontecimentos ocorridos no mundo europeu e americano que impulsionaram o seu surgimento, até matérias mais focais, como as principais publicações na área.

A institucionalização do termo Bioética, a Teoria Principialista, regida pelos princípios éticos de autonomia (respeito) às pessoas envolvidas em uma pesquisa científica, assim como a beneficência em participar do estudo, a sua não maleficência, abrangendo os menores riscos possíveis, e a justiça, com igualdade de condições para quaisquer países, sendo "ricos" ou "pobres", com garantias de direitos e, ainda, as críticas ao Principialismo, propondo a sua renovação, são pontos-chave da Bioética, pois tal perspectiva não comportava um corpo teórico uniforme capaz de dar conta da pluralidade de conflitos entre as diversas sociedades, incluindo tal teoria como seu artifício hegemônico (Diniz \& Guilhem 2008).

A cronologia de eventos que deram impulso à formação da Bioética, entendida, em linhas gerais, como "a ciência da sobrevivência humana", sendo também um "estudo que revitalizou a ética médica", o campo ou disciplina em "permanente construção, que deve oferecer ferramentas capazes de sempre proporcionar as melhores circunstâncias aos habitantes do planeta” (Costa 2008: 26) são as variadas formas de compreender o que vem a ser "Bioética".

Tais assuntos foram debatidos no artigo de Costa (2008), que no texto "O desafio da ética 
em pesquisa e da bioética" traça os caminhos pelos quais determinados episódios circundaram a sua formação, como o surgimento da bioética, com o pioneirismo de Potter, médico oncologista (Universidade de Wisconsin), que entendia a Bioética dentro de uma visão global, não restrita à moral das ciências biomédicas; a criação da Enciclopédia de Bioética do Kennedy Institute (1978), em que a área é definida como o exame moral interdisciplinar e ético das dimensões da conduta humana nas áreas das ciências da vida e da saúde (Stephen Garrard Post); os primeiros códigos de Nuremberg e de Helsinque, como códigos éticos de fora dos EUA que foram importantes pontos de referência para a atribuição da ética em situações de guerra e conflitos entre países e/ou experiências científicas duvidosas, humilhantes e degradantes, sendo tais episódios fundamentais para a compreensão do início das discussões sobre o tema ao redor do mundo (Costa 2008).

Um dos pontos significantes da emergência da Bioética discute a barbárie do Holocausto, na II Guerra Mundial, que resultou na elaboração do Código de Nuremberg (1947), um marco importante à dignidade da pessoa humana, documento com diretrizes éticas à realização de estudos com seres humanos, valorizando o consentimento de toda pessoa que participaria de uma pesquisa. Além dele, tem-se a World Medical Association (1964), publicada em Helsinque, Finlândia.

A Declaração de Nuremberg subsidiou a prática de pesquisa médica em oposição ao duplo standard (duplo padrão ético), benefício de países desenvolvidos em detrimento dos países pobres, e a Modificação da Assistência Sanitária, que incidiu um novo olhar sobre a clientela, ou seja, as pessoas (os pacientes), agora compreendidas como agentes morais, responsabilizando-se por sua própria saúde, sendo titulares de direitos, todos esses fatos são primordiais para o aparecimento da Bioética no cenário mundial. A área chegou ao Brasil tardiamente, mas hoje já comporta cerca de 848 CEP em todo o país (Costa 2008: 30, Brasil 2020)

Outro caso emblemático a respeito da importância do debate sobre Bioética está relacionado ao Estudo Tuskegee, que ocorreu no Alabama, EUA (1932-1972), conduzido durante 40 anos, com 399 homens negros com sorologia positiva para sífilis, que compuseram o grupo experimental do estudo e que não foram tratados nem informados sobre a natureza de sua doença, apesar da descoberta da penicilina (1943), antibiótico eficaz à sífilis, sendo que o grupo não teve acesso ao medicamento, eles foram acompanhados de 201 homens saudáveis, que pertenciam ao grupo-controle, tendo como 
"objetivo" o "estudo da história natural da doença", finalizando com a necropsia dos corpos (Costa 2008: 33).

Em Tuskegee, os homens do experimento recebiam placebos, como injeções, comprimidos, unguentos e tinham o seguro funerário garantido em troca de sua inclusão no projeto. As informações sobre os sintomas e os sinais decorrentes da sífilis eram interpretadas como se eles fossem portadores de "sangue ruim".

Posteriormente, a jornalista estadunidense Jean Heller, da Associated Press, desvendou o fato em 1972: mediante a investigação do Departamento de Saúde, Educação e Bem-Estar dos EUA, constatouse que 74 participantes sobreviveram à pesquisa, que foi um grande escândalo ético de caráter mundial (Costa 2008).

Afora esse episódio, a Bioética é repleta de outras histórias semelhantes. Pode-se relatar aqui o evento do ginecologista americano James Marion Sims, considerado um dos pais da ginecologia, que, no século 19 foi acusado de praticar cirurgias para curar as fístulas vesico-genitais em mulheres escravizadas, três delas imortalizadas na pesquisa da médica e historiadora Vanessa Gamble, da Universidade de Washington: Anarcha, Lucy e Betsy. Segundo a historiadora, somente em Anarcha, Sims realizou cerca de 30 cirurgias. O médico também registrou que Lucy chorava de dor e achava que ia morrer (Gamble 1995).

Além de performar cirurgias sem anestesias em mulheres negras, porque acreditava que elas eram mais resistentes à dor, argumento racista que até o momento presente ainda se pode observar no meio médico, Sims também chamava outros médicos para assistir às cirurgias, todos esses episódios, sem a prévia permissão de suas pacientes, pois eram os senhores que tinham suas posses e quem respondiam por elas legalmente (Gamble 1995).

O fato é que os defensores de Sims afirmam que ele era simplesmente um homem de seu tempo, que esses julgamentos com olhares de hoje acabam distorcendo vários comportamentos e as mulheres escravizadas com fístulas provavelmente queriam o tratamento, já que viver com esse problema era tão sofrível que teriam concordado em participar de seus experimentos (Holland 2017).

Até recentemente existiam três estátuas de Sims nos estados de Nova Iorque, Carolina do Sul e Alabama, nos Estados Unidos. Em 2018, após análise do comitê que revisa os monumentos da cidade, a estátua de Nova Iorque foi removida do Central Park e colocada no cemitério onde ele está enterrado, um dos vários momentos de reparação histórica vivenciada em nossa atualidade 
no que diz respeito a questões éticas, raciais e/ou humanitárias ${ }^{7}$.

Pode ser citado mais um exemplo: em um caso ocorrido no município de Santana (AP), de uma pesquisa da Universidade da Flórida, em parceria com a Fundação Oswaldo Cruz (FIOCRUZ), a Universidade de São Paulo (USP), a Fundação Nacional de Saúde (FUNASA) e a Secretaria Estadual de Saúde do Amapá (SESA), intitulada "Heterogeneidade de vetores de malária no Amapá”, de 2003 a 2005. O objetivo era analisar os vários tipos de transmissores de malária na região e para isso 40 moradores da comunidade quilombola São Raimundo do Pirativa, próximo à Santana, ganhavam uma quantia em dinheiro para participar da pesquisa, sendo que "por nove noites de trabalho por mês, os ribeirinhos receberiam $\mathrm{R} \$ 108,00$ capturando e alimentando mosquitos transmissores da malária, ou seja, $\mathrm{R} \$ 12,00$ por noite" (Santos \& Santos 2011: 147).

É essencial pontuar que muitos moradores eram analfabetos, com escassos recursos econômicos, ou seja, a comunidade em questão era considerada vulnerável. Além disso, as pesquisas entomológicas desse tipo devem ser realizadas por profissionais treinados, mas na pesquisa relatada não se estabeleceu critério de participação e os moradores afirmam que houve apenas um pequeno treinamento poucas semanas antes do começo do estudo (Martínez 2014). Segundo relato do senador Cristovam Buarque, responsável na época pela Comissão de Direitos Humanos do Senado, formada para analisar a situação, em reportagem ao jornal Folha de São Paulo:

"Diariamente, eles eram submetidos
a picadas de cem mosquitos
transmissores da malária. Cada
pessoa tinha de reunir 25 insetos
por vez dentro de um copo e, então,
eles colocavam o copo na perna para
que os mosquitos chupassem seu
sangue. Isso acontecia durante uma,
duas, três horas, o tempo que fosse
necessário para que os insetos ficassem
tão saciados de sangue que caíssem.
Depois, os insetos eram entregues aos
pesquisadores" (Folha de São Paulo 8
de janeiro de 2006).

Em nota, a Fiocruz explicou que o projeto enviado em 2001 para ser analisado pelo Comitê de Ética em Pesquisa da Universidade Federal do Amapá (CEP/UNIFAP) não mencionava o pagamento aos colaboradores nem a sua utilização como "isca humana" e que uma frase do texto original do projeto prevendo o uso de cobaias humanas teria sido omitida da versão em português. Com tudo isso, novamente, quem apresentou os danos foram os participantes quilombolas: foi constatado que $50 \%$ deles haviam sido contaminados com malária - apesar de que

7 Matéria do portal Geledés: "Sims era um salvador ou um sádico? Depende da cor das mulheres que você pergunta”. Disponível em: https://www.geledes.org.br/sims-era-um-salvador-ou-um-sadico-depende-da-cor-das-mulheres-que-voce-pergunta/. 
não se pode afirmar se os quilombolas foram contaminados com a experiência ou pelo local onde moravam (Folha de São Paulo 2006, Luz 2014).

Em se tratando de situações como as elencadas acima, Costa (2008) informa que entre os princípios aceitos em nossa tradição cultural, aqueles que são relevantes envolvendo seres humanos são: o respeito pelas pessoas (informação, compreensão e voluntariedade), a beneficência (não causar dano, maximizar os benefícios e diminuir possíveis danos) e a justiça (ofertar mais a quem mais precisa, os iguais devem ser tratados igualmente) e a não maleficência (da máxima deontológica primum non nocere, a fidelidade de compromisso com a pessoa), condutas que moldaram a teoria Principialista, que em 1979 passou a ser dominante na pesquisa científica e no campo assistencial, domínio teórico utilizado como ferramenta para mediar os conflitos morais na prática biomédica, sinônimo da própria bioética (Costa 2008).

A vulnerabilidade das pessoas torna-se um mote muito importante à Bioética, por sua dificuldade conceitual ou por inúmeras discussões de diferentes tópicos da ética em pesquisa, sendo que o baixo nível de educação dos participantes e a falta de acesso a serviços de saúde de qualidade são fatores determinantes à vulnerabilidade, devendo ser repensada e reavaliada, especialmente, nos países periféricos, culminando no Conselho de
Organizações Internacionais de Ciências Médicas (CIOMS), o qual institucionaliza que a pessoa comprometida de sua capacidade ou liberdade de consentir ou recusar-se a participar de uma pesquisa é um indivíduo vulnerável, e ainda que os países que não dispõem de mecanismos, regulamentações legais ou informações éticas tornam-se incapazes de impor sanções a patrocinadores ou a pesquisadores que violem diretrizes: "Se os pobres são submetidos aos riscos, e os ricos recebem os benefícios, há uma grave violação ao princípio da justiça: a pesquisa safári" (Costa 2008: 44). No Brasil, a primeira norma ética foi a Resolução Conselho Nacional de Saúde 196/1996, sendo que ela

incorpora, sob a ótica do indivíduo e
das coletividades, os quatro referenciais
básicos da bioética: autonomia, não
maleficência, beneficência e justiça,
entre outros, e visa assegurar os
direitos e deveres que dizem respeito
à comunidade científica, aos sujeitos da
pesquisa e ao Estado. (Brasil 1996: 1).

Assim como os demais princípios apreendidos pela teoria Principialista, percebe-se, com a resolução, um avanço significativo nos códigos de ética em pesquisa em nossa sociedade.

Atualmente, a Resolução 466/2012 está em vigor e trata das normas envolvendo pesquisas com seres humanos (Brasil 2012), a qual elabora um amplo protocolo para garantir aos grupos pesquisados a normatização eficiente, baseada em 
termos de assentimentos, o reconhecimento de indivíduos vulneráveis, a ponderação de benefícios pela participação em pesquisas, a assistência integral quando do uso de fármacos, dentre outras prerrogativas éticas e bioéticas fundamentais para o avanço de pesquisas nacionais e internacionais na área médica, biomédica e social.

Posteriormente à 466/2012, a Resolução 510/2016, também vigorando desde então, tratou das normas específicas para pesquisas nas áreas das Ciências Humanas e Sociais em todo o país:

cujos procedimentos metodológicos envolvam a utilização de dados diretamente obtidos com os participantes ou de informações identificáveis ou que possam acarretar riscos maiores do que os existentes na vida cotidiana. (Brasil 2016a: 1).

A Resolução 510/2016 está em processo de constante adequação nos CEP de Ciências Humanas e Sociais brasileiros por causa das características metodológicas das pesquisas etnográficas envolvendo seres humanos e que só podem ser autorizadas mediante a convivência prolongada com os grupos, por meio de vídeos e/ ou outras maneiras de consentimento e que têm sido aprimoradas desde então.

O campo da Bioética se encontra em nichos de construção de ideias e princípios que respeitam a diversidade humana, biológica e cultural, elementos eficazes à proteção de pessoas vulneráveis ou não. Para a Bioantropologia, o tema da bioética é um assunto indissociável, justamente por englobar em sua dimensão ética a feitura de projetos com/e em seres humanos ${ }^{8}$ substancialmente vulneráveis. Neste artigo isso será discutido no contexto de uma síndrome genética, a Doença Falciforme, partindo do cotidiano dos interlocutores, de seus relatos sobre a própria doença e de constantes envolvimentos éticos, como a pesquisa antropológica com autorização prévia. Mas antes, deve-se tratar sobre a "vulnerabilidade".

\section{AS DIVERSAS VULNERABILIDADES NO CAMPO DA BIOÉTICA}

Usa-se aqui o sentido de Kottow (2008) para vulnerabilidade, descrito por Morais (2010) como:

$\mathrm{O}$ atributo antropológico dos seres humanos devido ao simples fato de estarem vivos. Ser vulnerável significa estar susceptível a sofrer danos. Algumas pessoas são afetadas por circunstâncias desfavoráveis (pobreza, educação, dificuldades geográficas, doenças crônicas ou outros infortúnios) que as tornam mais expostas: padecem de perda de capacidade ou de liberdade; tem reduzida a gama de oportunidades de escolha dos bens essenciais para suas vidas (Morais 2010: 333).

8 Para Oliveira (2010: 30), as pesquisas com seres humanos (investigação das Ciências Sociais, de interlocução) e em seres humanos (investigação das Ciências Biomédicas, de intervenção) têm o compromisso ético de respeitar o sujeito envolvido na pesquisa, ainda que as duas intervenções - 'verbais' ou de 'procedimento laboratorial' - consigam dar conta de atitudes éticas, mantendo-se o antropólogo com a responsabilidade ética da "definição de o quê, como e quando publicar". 
O conceito não é fechado em si mesmo, pois ainda não existe um consenso entre os estudiosos do tema. Para tanto, é importante entender que, segundo a Resolução 196 (Brasil 1996), vulnerabilidade é:

O estado de pessoas ou grupos que, por quaisquer razões ou motivos, tenham a sua capacidade de autodeterminação reduzida ou impedida, ou de qualquer forma estejam impedidos de opor resistência, sobretudo no que se refere ao consentimento livre e esclarecido (Brasil 1996:3).

O artigo "Populações especiais: vulnerabilidade e proteção", de Rogers e Ballantyne (2008), discorre a respeito dessa palavra ou conceito tão amplamente discutido nas Ciências Biomédicas e no campo da ética, para eles, vulnerabilidade seria "a incapacidade [dos envolvidos em pesquisas científicas] de proteger os próprios interesses" (Rogers \& Ballantyne 2008: 123, adendo nosso). Logo, a vulnerabilidade "existe como um espectro, não é nem presente nem ausente", discutindo-a como tema principal e afirmando que ela está associada às desigualdades sociais e às relações de poder entre aquele que participa voluntariamente de uma pesquisa científica e o pesquisador, sendo a prima facie das considerações ao entendimento das "capacidades mentais reduzidas", pela sensibilidade de ter uma doença, por limitação financeira, promessa de benefícios etc. (Rogers \& Ballantyne 2008: 123)
Os autores pontuam duas vulnerabilidades: a intrínseca, que é "causada por características que tem a ver com os próprios indivíduos, tais como doença mental, deficiência intelectual, doença grave ou os extremos de idade (crianças e idosos)" (Rogers \& Ballantyne 2008:123); e a extrínseca, aquela que é "ocasionada por circunstâncias externas, como falta de poder socioeconômico, pobreza, baixa escolaridade ou carência de recursos", conceitos envoltos em questões éticas relevantes que estão imbricadas, possuindo ambas as vulnerabilidades (Rogers \& Ballantyne 2008: 125).

Rogers e Ballantyne (2008) citam como exemplos os bebês prematuros da Bolívia com a Síndrome Respiratória Aguda Grave (SARS), da sigla em inglês Severe Acute Respiratory Syndrome, um dos sintomas de alta gravidade da atual pandemia global, a Covid-19. No caso dos bebês bolivianos, ela foi associada a questões de natalidade, todos vulneráveis por não terem acesso a surfactantes nem a instalações de cuidados intensivos necessários à sobrevivência. Outro exemplo foram crianças com HIV sem AZT (Zidovudina), na África, sem acesso à Terapia Antirretroviral (TARV), populações com vulnerabilidades extremas, que foram submetidas a experimentos exatamente por sua condição de pobreza (vulnerabilidade intrínseca e extrínseca). 
Os pesquisadores citam como questões extrínsecas: a "falta de poder" (por questões de gênero, raça, idade, sexo ou populações indígenas, suscetíveis em relação à sociedade nacional) e outros riscos ligados à integralidade física, riscos psicológicos, sociais e econômicos, desvantagem educacional (o que dificulta o entendimento do TCLE), o não acesso a cuidados básicos de saúde e outros. Já as questões intrínsecas, basicamente, seriam a não capacidade para decisões, como é o caso de bebês, crianças, e adolescentes; e a incapacidade mental de pessoas dependentes de cuidados médicos e de idosos.

Por outro lado, o polêmico texto "Pagamento a participantes de pesquisa”, de Castro (2008: 219), inicia com algumas indagações: "Os sujeitos humanos devem ser pagos por participarem de pesquisas biomédicas? O que pode haver de errado, se assim o for, em pagar sujeitos humanos para tomar parte em estudos biomédicos? É aceitável que a pesquisa biomédica seja tida como uma oportunidade de ganhar dinheiro?", abordando argumentos a favor e contra o pagamento a sujeitos participantes de pesquisas na área da saúde.

Castro (2008) descreve casos sobre o pagamento em pesquisas, como o de Reed, que pagou \$ 100 (cem dólares americanos, em ouro) para voluntários que quisessem participar de um experimento sobre a febre amarela (e mais 100 para os que contraíssem a doença e/ou morte), soma que constava no TCLE do estudo! O autor declara que, hoje em dia, muitas pessoas são pagas para participar de pesquisas científicas, todavia, "gera uma tensão preocupante entre a necessidade de recrutar sujeitos humanos e a de assegurar sua capacidade de decidir livre e independentemente" (Castro 2008: 222), isto é, o dinheiro poderia proporcionar ao sujeito uma decisão arbitrária, contrária ao que foi estabelecido em Nuremberg, o que gera muitas controvérsias (Castro 2008).

O autor supõe que o altruísmo, talvez, não deva ser a única forma de incentivo à participação em pesquisas científicas, entretanto, no campo das Ciências Biomédicas, existem muitos avanços das experiências que contribuem à participação voluntária e, assim sendo: "Nessa interpretação extrema, parece não haver nenhuma justificativa para pagamentos, sejam eles de qualquer espécie" (Castro 2008: 222).

Mais adiante, declara: "Em vez de prestar atenção no debate sobre pagamento versus não pagamento, talvez se devessem focalizar as condições sob as quais o pagamento poderia ser oferecido" (Castro 2008: 222), distinguindo três exemplos de pagamento: o modelo de mercado, em que "o mercado é o local onde se usa dinheiro para encorajar as pessoas a trocar bens que elas possuem ou para oferecer serviços que estão em 
demanda, a ideia é ser sensível às tendências do mercado" (Castro 2008: 229); o de saláriopagamento, em que a "participação em pesquisa em pé de igualdade com o trabalho não-qualificado assalariado" (Castro 2008: 230), e o modelo de reembolso: "centrado nas despesas contraídas em decorrência da participação do indivíduo, para cobri-las" (Castro 2008: 231).

Castro (2008) afirma também que a vulnerabilidade é preocupante com as possíveis consequências de oferecer pagamento:

\begin{abstract}
Nas Filipinas, crianças de rua que foram recrutadas para pesquisas receberam pagamento em forma de biscoitos ou pães. Mesmo quantias pequenas podem servir como incentivos para populações extremamente vulneráveis" (Castro 2008: 242).
\end{abstract}

Além disso, pessoas encarceradas também foram/são envolvidas em pesquisas científicas, como as experiências nazistas da II Guerra Mundial (coercitivas). Na atualidade, nos EUA, uma pesquisa sobre malária em uma prisão de Illinois (paga), gerou efeitos colaterais indesejados, tornando o incentivo ao pagamento uma questão contraditória. Castro (2008) conclui descrevendo algumas regras para o pagamento, como "a proibição da menção de pagamento em anúncios, para minimizar a possibilidade de indução indevida" ou a "permissão apenas de presentes não monetários como um sinal de agradecimento (anunciado e oferecido após o ensaio)" (Castro 2008: 246-250).

Será que tais condições são válidas sem usar de coerção? O texto é impreciso para quem o lê e, se esse não for o desígnio do pesquisador, então, continua-se em dúvida sobre o que ele propõe, o que torna o "esclarecimento ético" do pagamento para participação em pesquisa muito conflitante, sendo necessário rever tais conceitos, especialmente, no Brasil, constituído de tantas desigualdades sociais com vulnerabilidades em diversos aspectos.

Vale ressaltar que no Brasil, as resoluções tratam apenas sobre o ressarcimento dos participantes da pesquisa, que é a "compensação material, exclusivamente de despesas do participante e seus acompanhantes, quando necessário, tais como transporte e alimentação” (Brasil 2012: 3).

Com relação ao consentimento livre e esclarecido, observam-se diferenças na Resolução 510/2016, quando comparada às resoluções anteriores. Nela, o consentimento pode ser obtido em qualquer etapa da pesquisa, assim como poderá ser retirado, podendo ainda ser comunicado e obtido de várias formas, de acordo com as características dos participantes:

Registro do consentimento ou do assentimento: documento em qualquer meio, formato ou mídia, como papel, áudio, filmagem, mídia eletrônica e digital, que registra a concessão de consentimento ou de assentimento livre e esclarecido, sendo a forma 
de registro escolhida a partir das características individuais, sociais, linguísticas, econômicas e culturais do participante da pesquisa e em razão das abordagens metodológicas aplicadas (Brasil 2016a: 4).

No artigo "Consentimento livre e esclarecido: ainda uma ferramenta útil na ética em pesquisa?”, Luna (2008) pondera sobre os usos do TCLE, que desde as violações da II Guerra Mundial é usado para impedir pesquisas de caráter abusivo entre pessoas (prisioneiros de guerra, por exemplo) e

\begin{abstract}
embora não seja o primeiro documento na área de ética em pesquisa, ele é paradigmático e um dos documentos mais bem conhecidos, sua intenção era a de eliminar a pesquisa antiética, e o foco adotado foi sobre o TCLE (Luna 2008: 154).
\end{abstract}

Mesmo após o Código de Nuremberg e a 'fé na ciência e no progresso', casos como de Tuskegee e outros, continuaram ocorrendo, arriscando a vida de pessoas vulneráveis "sem seu consentimento ou aprovação". A autora aborda inúmeras situações nas quais o documento foi, deve ou é usado, como uma "regra de ouro" no domínio da ética em pesquisa, especialmente nos países em desenvolvimento (Luna 2008: 155-162). Para Luna (2008), o TCLE é demasiado formal, pois

frequentemente, o consentimento livre e esclarecido é uma comunicação única e unidirecional, um obstáculo que os pesquisadores precisam transpor para irem para a etapa seguinte do seu protocolo de pesquisa. (Luna 2008: 162-163 apud Heise \& Wood 2005: 19).
De forma geral, a autora considera que o TCLE não é exatamente "claro" como deveria ser, ao contrário, é um documento que dificulta o seu entendimento, pois as pessoas envolvidas em estudos acadêmicos são socioculturalmente diversas em termos de "língua, religião, economia e tradição", lembrando ainda que "uma grande porcentagem da população é altamente vulnerável devido às desigualdades estruturais, ao racismo, à pobreza, à baixa alfabetização e à disparidade de gênero" (Luna 2008: 163 apud Bhan et al. 2006: 39).

A pesquisadora conclui informando que a pobreza (escassez de recursos) é um problema a ser debatido, "um convite à exploração", sendo um desafio para a pesquisa em geral e o TCLE "uma condição necessária, mas não suficiente" (Luna 2008: 181-182).

Diante dos temas sobre ética, bioética e desafios na pesquisa científica expostos é importante refletir sobre como as vulnerabilidades associadas às pessoas com Doença Falciforme na região amazônica podem influenciar na autonomia dos indivíduos participantes do estudo em relação ao consentimento de pesquisa, além de outras etapas do trabalho de campo.

Valêncio e Domingos (2016) refletem sobre essas condições apesar da carência de publicações sobre o tema. De acordo com os autores, a vulnerabilidade biológica se manifesta nas implicações clínicas da 
AF: dor, intervenções clínicas e cirúrgicas, danos físicos e suas consequências no âmbito psíquico, estigmatização, preconceito, limitações laborais etc.

Além disso, a vulnerabilidade cultural da AF está associada à convivência com os piores índices de escolarização e desenvolvimento econômico, sobretudo na população negra, também submetida ao racismo e intolerância religiosa (Valêncio \& Domingos 2016). Nesse sentido, o processo de consentimento informado nas pessoas com AF deve ser avaliado com cautela, considerando as suas singularidades (Valêncio \& Domingos 2016).

Por conseguinte, é imprescindível repensar o modelo documental do TCLE e, acima de tudo, enfrentar as desigualdades entre os países com maior respeito às pessoas envolvidas nos projetos de pesquisa, a fim de beneficiar os grupos participantes, dando-lhes maior dignidade. Podemos começar a fazê-lo no Brasil. Mas como pensar a Bioética na área da Bioantropologia?

De que forma pode-se refletir sobre a aplicação da Ética na abrangência do trabalho de campo entre indivíduos com doenças crônicas, como a Doença Falciforme, com pessoas consideradas vulneráveis pela cronicidade da enfermidade e outros elementos bioculturais? É o que se pretende discutir daqui em diante.

\section{HEMOCENTRO COMO ALDEIA E 0 ENFOQUE BIOÉTICO}

A Aldeia pesquisada ou lócus de observação foi um hemocentro na cidade de Belém, estado do Pará, Região Norte. Os nativos foram as pessoas com o diagnóstico confirmado de Anemia Falciforme (AF, a forma sintomática da doença) que faziam acompanhamento de sua evolução clínica e multiprofissional na Fundação Centro de Hemoterapia e Hematologia do Estado do Pará (HEMOPA). As miçangas como artefatos de "trocas por informações" foram documentos técnicos, como o projeto de pesquisa e o TCLE, seguindo a Resolução 196/96 do Conselho Nacional de Saúde (CNS), posteriormente substituída pela Resolução 466/2012 e em seguida complementada pela Resolução 510/2016, ambas em vigência.

O laudo de ancestralidade fornecido após a análise genômica do grupo estudado e imediatamente informado durante a leitura do TCLE também pode ser entendido como o corpus inscriptorum, contendo as narrativas dos antepassados genéticos do grupo, que são os instrumentos de feedback com os participantes da pesquisa na qual fomos aceitos no decorrer da vivência pelos caminhos do Hemocentro (Giumbelli 2002: 97-98, Peirano 1995).

É fundamental destacar que a entrada em campo depende da apresentação no local de uma 
carta de recomendação do projeto de pesquisa pelo pesquisador principal, o cadastro da folha de rosto digital na Plataforma Brasil, a assinatura de próprio punho e o carimbo do professor responsável pela pesquisa, o Certificado de Apresentação de Apreciação Ética (CAAE), ou seja, o número de registro de aprovação no CEP/Plataforma Brasil, dentre outras comprovações atualmente obrigatórias antes de qualquer pesquisa científica que envolva seres humanos, embora a abordagem específica sobre as documentações e aprovações prévias necessárias às pesquisas em Ciências Humanas e Sociais tenham sido posteriormente regulamentadas (Luna 2008, Brasil 2012).

Os dados e registros em questão constituem a primeira aceitação do estudante aspirante a bioantropólogo, que precisa aguardar o parecer técnico de um CEP, que tem um prazo de 30 a 60 dias para emitir a autorização do estudo ao pesquisador - que não é o discente que está no front, mas sim, geralmente, o seu orientador, porque até aquele momento o aluno de pós-graduação é apenas um sopro de areia cercado de invisibilidade -, à espera do parecer consubstanciado favorável para a entrada em campo. Somente após esse caminho, o estudante - agora proclamado com o seu ditame - pode finalmente dar início aos imponderáveis da pesquisa científica - Malinowski era feliz e não sabia.
O trabalho de campo do bioantropólogo na abordagem da saúde e da doença cursa algumas passagens que são realmente distintas daquelas tradicionalmente trilhadas com a imersão de estudos nas áreas da Antropologia Social/Cultural e, até mesmo, da Arqueologia - que precisa de documentos mais específicos, por exemplo, autorizações do Instituto do Patrimônio Histórico e Artístico Nacional (IPHAN), para intervenções (escavações) em sítios arqueológicos ou o contato prévio com comunidades indígenas ou ribeirinhas para conviver entre os sujeitos pesquisados. $\mathrm{Na}$ Antropologia Social, os métodos de pesquisa de campo em serviços de saúde podem ser descritos como o uso da socialização e da observação, na criação de laços, de proximidade e distância do pesquisado, que são práticas culturais que englobam relações sensíveis entre o pesquisador e o pesquisado (Ferreira \& Fleischer 2014).

No contexto da Bioantropologia, necessitase com frequência da submissão do projeto de pesquisa a um Comitê de Ética institucional. Ele, como a própria rubrica indica, é um conselho técnico que valida o cumprimento de diversos preceitos éticos nas pesquisas com seres humanos, a fim de evitar a exposição das pessoas a situações antiéticas, insalubres, vexatórias, que causem malefícios na integridade física e moral dos sujeitos, constrangimentos, dentre outros 
princípios adotados na área da Bioética, como a autonomia, a justiça, a beneficência e a não maleficência (Diniz \& Guilhem 2008, Rogers \& Ballantyne 2008, Fonseca 2010).

A observação do Outro na instituição de saúde pública referida é circundada por um Procedimento Operacional Padrão (POP), que exige dos discentes-pesquisadores uma conduta que seja similar ao do corpo técnico que acompanha os usuários no atendimento de rotina: é preciso que o bioantropólogo modifique o seu métier, desde a vestimenta que costuma usar diga-se mais informal - adotando o uso de um “jaleco”, acessório habitual no local -, passando por um ritual ${ }^{9}$ de reconhecimento dos espaços e rotinas na recepção dos usuários do Sistema Único de Saúde (SUS), nesse caso, de clínica hematológica, até a observação do modo como os interlocutores são acolhidos no dia a dia nos setores de ambulatórios médicos, odontológicos, de fisioterapia, enfermagem, psicossocial e urgência que compõem o hemocentro.

Munidos de todo o indumentário padrão: jaleco branco, sapatos fechados, crachá de identificação, TCLE, gravador digital, prancheta e questionários, os aprendizes estão prontos para o seu primeiro dia em campo. Normalmente, porém, o início da pesquisa é desolador, a impressão que se tem é a de estar sozinho, numa praia deserta, olhando o barco a motor desaparecer no horizonte... Aos moldes clássicos! E de certa maneira, é isso mesmo o que acontece, porque, naquele momento, os pesquisadores estão desamparados, sem livros ou teorias e, literalmente estão lá, no lugar de sua pesquisa (Geertz 2000).

Durante a pesquisa de campo, as pessoas que se encontravam na sala de espera aguardavam ansiosamente o atendimento médico, um dos espaços no qual a pesquisa ocorreu. Após duas ou três abordagens com cada interlocutor, no mesmo dia, quando a sorte lhes sorria, os entrevistados relatavam a respeito de suas vidas, angústias, medos, euforias, impressões de saúde e doença, sobre o seu próprio diagnóstico, seus credos, preconceitos, entre tantas perguntas ordenadas no formulário semiestruturado, que fora anteriormente aprovado pelo CEP.

A abordagem com cada interlocutor em campo é muito particular, neste caso, depende do momento em que se percebe que o sujeito aparentemente está descontraído e, necessariamente, sem crise de dor. Em geral, sucedeu ser imprescindível estar presente

$9 \mathrm{Na}$ ocasião, as chefias de cada clínica e assessorias técnicas conduziram os estudantes para serem formalmente apresentados nos locais dos diversos ambulatórios. A conduta ocorre com todos os pesquisadores, sem exceção, mesmo aqueles que já fizeram parte do hemocentro como antigos servidores públicos, como é o caso de uma das pesquisadoras do estudo. 
bastante cedo ao hemocentro, antes dos pacientes chegarem ao local. Na recepção de ambulatório era de praxe recolher a agenda médica, anotar ou decorar os nomes dos interlocutores, idade, cidade, sexo, horário e tipo de consulta do dia para fazer a chamada e iniciar a entrevista.

A prioridade era manter a observação do momento em que o interlocutor chegava e confirmava a sua consulta para, posteriormente, iniciar a primeira abordagem: apresentar-se ao nativo. O momento da aceitação do nativo é único. Ambos, pesquisadores e pesquisados, costumam expressar certa cumplicidade e ao final da consulta médica, iniciam a "conversa com finalidade" (Minayo 2000: 90). Obviamente, nem todos os interlocutores concordavam em participar do estudo, porém, as justificativas se mostravam sempre afinadas, como: "Tenho hora certa para voltar ao meu município de origem”, "Tenho que visitar um parente", "Eu não terei tempo hoje", e demais formas de dizer "não", todavia, os diálogos com as pessoas com $\mathrm{AF}$ nos ambulatórios fluíram com apropriada segurança depois de se explicar os principais objetivos da pesquisa via TCLE e adotando a percepção biossocial da Doença Falciforme partindo das narrativas dos interlocutores.

As vulnerabilidades da $\mathrm{AF}$ se encontram explicitadas na vivência de muitos interlocutores.
Silva e Silva (2013) analisaram a vulnerabilidade biossocial desses sujeitos descrevendo sobre a baixa renda familiar, o déficit escolar e a discriminação sociorracial do grupo, sendo que tais indivíduos ainda apresentam as restrições físicas impostas pela doença, associadas a dificuldades de acesso aos serviços de saúde, sobretudo, entre as populações ribeirinhas (Silva \& Silva 2013, Silva 2015).

O cuidado no momento de obter o consentimento dos pesquisados recaiu principalmente sobre a linguagem utilizada na aplicação do TCLE e durante a condução da pesquisa, de maneira acessível, acolhedora, respeitando sua autonomia e não reforçando tais vulnerabilidades, ao contrário, dando-lhes visibilidade, a fim de problematizar as políticas públicas e sociais para essa população. Outro aspecto considerado no consentimento, conforme explicitado por Valêncio e Domingos (2016), foi deixar claro aos sujeitos que a participação na pesquisa não estava vinculada à continuidade do seu tratamento na rede de saúde.

O critério de seleção dos sujeitos da pesquisa, a título de delimitação, foi eleger apenas as pessoas com diagnóstico confirmado de AF. A sigla para identificar a doença tanto na nomenclatura genética, médica e laboratorial quanto no prontuário eletrônico do hemocentro é conhecida como $\mathrm{Hb} S \mathrm{~S}$, ou seja, que aquela pessoa possui um alelo mutante em sua hemoglobina ( $H b S)$, 
os conhecidos "glóbulos vermelhos" do sangue, mutação chamada então de $S S$; para os indivíduos ditos de hemoglobina normal, a mesma sigla é representada com $A A$ (Guerreiro et al. 1994, 1999, Cardoso \& Guerreiro 2010).

Durante o ano de 2011, no período da pesquisa de mestrado, foram realizadas 45 entrevistas extensas e, muitas vezes, bastante tocantes, um risco não esperado antes do TCLE. Os interlocutores apresentavam declarações comovidas, com choro discretamente contido, lágrimas espontâneas e soluços enternecidos que são quase indescritíveis no sentido de atravessar o momento sem "objetivamente se neutralizar" diante do andamento do diálogo. Tal situação de cunho sensível é difícil de refrear diante do anseio de compreender o universo do Outro, porque o domínio emotivo durante a entrevista é subjetivo. A ressalva do sentimento mútuo é importante porque o ato de se encontrar perante o imponderável é um estranhamento essencialmente humano e, por isso, pode ocasionar em parar a entrevista para "respirar", mudar de assunto, achegar-se ao entrevistado, perguntar se está tudo bem e seguir, mesmo com o anseio à flor da pele, que nem sempre pode ser expresso durante a pesquisa de campo.

Outras narrativas informavam sobre a demora do atendimento no SUS, do incômodo rotineiro por quilômetros e quilômetros de distância percorridos pelos interlocutores, que saíam de diversas cidades do interior do Pará até encontrar acolhimento médico especializado apenas em Belém ou mesmo pela longa espera no hemocentro devido ao grande número de consultas realizadas ao dia, principalmente, para aquelas pessoas que relataram momentos de dores diversas.

Os sintomas mais comuns relatados pelas pessoas com AF foram dor pélvica, no "corpo inteiro", nos ossos, nas pernas, no baço, nos rins, nas "juntas” (algia nas articulações), nos tecidos bucais, na coluna cervical, epigástrica, nos braços, tornozelos, e demais sintomas extremamente desagradáveis que constituem a experiência de viver com $\mathrm{AF}$ em períodos de aflição ou crise. Dados dos prontuários médicos que relatavam a evolução clínica dos interlocutores desde o primeiro atendimento até o último exame de rotina também foram recolhidos e analisados, com o intuito de visualizar o acompanhamento e adesão ao tratamento (Silva \& Silva 2013).

Além disso, assuntos como renda familiar, sensação ao ser diagnosticado, discriminação, preconceito, apoio familiar, religiosidade, informações sobre $\mathrm{AF}$, tratamentos não acadêmicos, vivências, deslocamentos e demais sociabilidades do cotidiano das pessoas com o agravo foram narradas ao longo de oito meses de trabalho de 
campo no Hemopa. Algumas falas ${ }^{10}$ mostram

aspectos bioculturais do agravo:

"A gente abusa de tá vindo, sofro um calafrio, é muito ruim, depois que ela tirou o baço [a filha], as crises e internações acabaram. Assim, na verdade, tranquilo não é. Os pacientes com anemia falciforme são uma caixinha de surpresas, tem que tá preparado pra qualquer coisa a qualquer hora" (Alzira, Do lar, Mãe de adolescente de 14 anos com AF, município de Jacundá, estado do Pará).

"Ele é muito tímido, calado, não gosta de viver com outras crianças, eu aconselho ele a ir brincar, é atrasado na escola, não consegue acompanhar os estudos, é o jeitinho dele mesmo, ele é retraído, fechado" (Raimunda, Doméstica, Mãe de adolescente de 13 anos com AF, município de Abel Figueiredo, estado do Pará).

"No próprio ambiente de saúde já sofri discriminação. Quando estava internada e dizia que as dores não passavam, elas [as enfermeiras e técnicas de enfermagem] diziam que era psicológico. Isso causava tristeza. Tem muitas pessoas que não entendem que essas dores são tão fortes, que precisam de opioides, mas que são paliativos, não resolvem o problema com a sangria e a transfusão, os profissionais não entendem que a dor é complicada. Eu considero isso muita negligência" (Joana, pedagoga, 35 anos, pessoa com AF, município de Belém, estado do Pará).

"Quase todo dia eu sinto dores nos ossos, na cabeça, no corpo. Eu sou ruim pra comer, eu não sinto vontade de comer. Tem dia que eu tô bem, mas quase todo mês eu tenho crise de dor, principalmente no período menstrual, eu já pelejei pra passar no ginecologista porque eu não quero mais menstruar, porque desde a primeira vez que eu menstruei eu vim parar pra Belém” (Aldalice, estudante, 25 anos, pessoa com AF, município de Marabá).

"É um pouco complicado pela dificuldade de morar longe, não tenho condições de comprar as passagens, dou graças a Deus a saúde dar pra gente (TFD). A passagem custa R\$ 40,00, são quatro passagens [para a criança e o pai, ida e volta, ao todo ambos gastam $\mathrm{R} \$ 160,00$, mais do que o pai arrecada por mês revendendo o excedente da farinha que produz]. Eu não tenho condições de comprar e eles só dão a passagem mesmo. Quando a gente vem, fico na casa do pai do meu cunhado, aqui no Jurunas, venho a pé pro Hemopa" (Jairo, agricultor, pai de criança de 10 anos com AF, município de Oeiras do Pará).

As leituras de prontuários clínicos durante a pesquisa de campo no hemocentro foram momentos cruciais de formação acadêmica bioantropológica e bioética, porque nesses documentos existem elementos que são relevantes na constituição de saúde e doença dos sujeitos da pesquisa, que estão para além dos sintomas especificamente.

Os prontuários, em geral, descreviam a respeito do primeiro atendimento que levou o paciente a ser encaixado como "tratamento para doença falciforme", muitas vezes referenciado de outras unidades de saúde como suspeita de hepatite, leucemia ou reumatismo, sendo que muitos não tiveram acesso ao teste do pezinho

10 Durante a fase do trabalho de campo no mestrado (2011), o TCLE foi confeccionado para garantir o anonimato dos relatos, sendo que as entrevistas foram exclusivamente publicadas sem identificação dos participantes nem uso de imagens ou vídeos, utilizando nomes fictícios como os citados acima. Quase no final da pesquisa, foram feitas duas fotografias de uma das entrevistadas durante uma conversa informal de corredor, que foram arquivadas. Foi pedida autorização para uso das imagens em questão, alguns anos depois, para uma palestra fechada, que foi concedida. 
durante a infância ou adolescência. Em muitos documentos, observa-se a subnotificação de raça/ cor, que não era requisito importante de coleta de informações, sendo hoje um dado fundamental para compreender a relação entre AF e ancestralidade genética, ou ainda a distribuição de medicamentos que são usados na terapêutica de $\mathrm{AF}$, que nem sempre eram distribuídos de forma regular pelo hemocentro por causa de algumas falhas de reposição administrativa ou logística.

Nos mesmos documentos, notam-se relatos sobre outras doenças genéticas ou crônicas associadas à AF ou casos de não aceitação da condição genética de pacientes pelos pais e ou parentes, com relatos descritos nos exames psicológicos. Outros casos graves, como crises de priapismo, necroses ósseas, sequelas de AVC, a descontinuidade no tratamento devido a situação de renda dos pacientes, dentre outras manifestações clínicas e socioculturais importantes também faziam parte das vicissitudes dos pacientes. Todos, instrumentos bioéticos que devem ser levados em consideração no momento da descrição densa sobre as pessoas pesquisadas, levando em consideração a confidencialidade, a privacidade e o respeito com eles, preservando as suas identidades, sempre que for o caso.

Para entender as representações sobre a Doença Falciforme é adequado considerar o contexto biocultural no qual os indivíduos realizam suas práticas de convivência, labores, sociabilidades e, principalmente, organizam itinerários terapêuticos que são ordenados no domínio de suas estruturas socioeconômicas, ambientais e humanas. Idealmente é interessante que o bioantropólogo em campo possa realizar a proximidade com os sujeitos da observação de modo discreto, com um diálogo preliminar como se resguardasse um segredo, para que se habituem ou consigam figurar o pesquisador de maneira mais amigável em campo.

Quanto maior a afinidade que a abordagem do primeiro contato apresente como retorno (consentimento/assentimento) e mais estreitas possíveis forem as relações com o pesquisado, o entrevistador conseguirá avizinhar-se das informações que pretende, arranjando a tão desejada adjacência com o agrupamento que ambiciona estudar. Em outras palavras, o pesquisador consegue ser aceito pelos indivíduos, em definitivo (Peirano 1995).

O envolvimento bioético da AF no Pará está relacionado à forma de estar em campo, pois na pesquisa social, as autorizações, os riscos, os modelos de diálogo com os sujeitos da pesquisa, os benefícios e as trocas de informações entre os pesquisados e o bioantropólogo são, todos, 
instrumentos que lidam diretamente com sensibilidades diversas e, mesmo o risco mínimo ${ }^{11}$, - como uma resposta emocionada sobre um assunto delicado no cerne de uma doença crônica - deve ser considerado, risco esse que, de modo geral, não é pensado de modo crítico.

O conceito envolve a ideia de procedimentos ou intervenções médicas e não um ímpeto bastante humano como o ato de se emocionar ou se chocar diante de uma pergunta inesperada, portanto, é preciso repensar conceitos sobre novos riscos envolvidos em pesquisas antropológicas, por exemplo, considerar os diversos riscos como fatores cruciais para o envolvimento de pessoas adoecidas e/ou em situação de vulnerabilidade social (Guerriero \& Bosi 2015).

Havia uma inadequação da atual resolução diante das características da pesquisa em Ciências Humanas e Sociais, que possuem diferenças em relação às Ciências Biomédicas, além do uso do conceito de "risco" em diretrizes à CHS no ambiente da saúde, apontando as interfaces e as tensões que discutem "mérito científico e avaliação ética", abordando os empecilhos no

diálogo interparadigmático na pesquisa
em saúde, consideradas as características
das distintas tradições, a ancoragem da
CONEP na perspectiva positivista e a
defesa da hegemonia dessa tradição

diálogo interparadigmático na pesquisa

11 De acordo com a Resolução 510/2016 (Brasil 2015: 4), o risco da pesquisa envolve a "possibilidade de danos à dimensão física, psíquica, moral, intelectual, social, cultural do ser humano, em qualquer etapa da pesquisa e dela decorrente", o que não foi observado de modo contundente durante a nossa pesquisa.
A Resolução 466/2012 não dava conta do trabalho de campo do antropólogo. Era notório que existia uma inconformidade dessa resolução para a grande área das CHS, pois os méritos e vicissitudes da pesquisa social versus pesquisa biomédica são diferentes, ainda que complementares e estão "para além dos comitês de ética em pesquisa”, porque a mera autorização assinada por um protocolo de pesquisa não garante a legitimidade da empatia com o nativo. O documento, talvez, avalize a autoridade do pesquisador, nada longe disso.

\section{DESAFIOS BIOÉTICOS E QUEBRA DE PARA- DIGMAS}

Cinco anos após a primeira entrada em campo na ocasião do curso de mestrado (2011), a pesquisa com pessoas com AF continuou entre o final de 2016 e início de 2017 durante o curso de doutorado em Bioantropologia (UFPA) com o projeto de pesquisa "A Doença Falciforme na Amazônia: as intersecções entre identidade de raça/cor e ancestralidade genômica no contexto paraense".

Essse novo estudo abordou a AF na investigação bioantropológica da Era da Genômica (Santos \& Maio 2005), agora com 
um $n$ de 60 pessoas entrevistadas, também de abordagem qualitativa. Todavia, muitos empecilhos foram enfrentados no âmbito do site da Plataforma Brasil, novamente, com inúmeros documentos para a autorização do estudo na avaliação ética que então se iniciava.

O tempo de espera foi longo, de exatos seis meses, por uma grande dificuldade de comunicação entre a pesquisadora principal e os códigos eletrônicos exigidos pelo site da Plataforma, com longa demora e pouca resolução nas respostas do CEP, como um documento com assinatura digitalizada do responsável pelo projeto, que voltou para o ambiente do site de registro da pesquisa, pois é necessário que seja assinado de próprio punho, atrasando o início da pesquisa por três meses, além de um dos filtros de escolha do tipo de pesquisa não se adequar à proposta do projeto, pois o site entendia "análise genética" apenas como "questões laboratoriais" e não "antropológicas", o que tornou o aceite mais demorado.

Com os devidos ajustes resolvidos, a resposta da assinatura inadequada demorou 30 dias para ser analisada e, após apresentar o documento adequado, outros detalhes e carimbos foram exigidos, sendo, finalmente, encerrados e o projeto de pesquisa, obtendo parecer favorável, um semestre após a submissão, detalhes de comunicação e encaixe de novas propostas de pesquisa que precisam ser revistas, porque o sistema on-line foi criado para uma área afim, o que dificulta sobremaneira a pesquisa de campo nas CHS que segue protocolos outros senão os seus próprios.

Dessa vez, o hemocentro como aldeia tinha uma proposta diferente: analisar as questões bioculturais dos interlocutores que pudessem descrever as manifestações clínicas da AF, com a quantidade e a gravidade dos sintomas do agravo, os relatos socioeconômicos sobre escolaridade, renda, autodeclaração de raça/cor, idade e gênero, como também foram realizados testes genéticos para análise da ancestralidade genômica dos interlocutores, com o intuito de compreender a interação entre as categorias levantadas.

Em relação ao $\mathrm{TCLE}^{12}$, houve um adendo relevante: os participantes poderiam autorizar o uso de imagem, áudio e vídeo com as entrevistas, que ocorreram duas vezes com cada pesquisado, sendo a primeira etapa a do levantamento socioeconômico e de saúde dos últimos 12 meses, descrevendo os sintomas mais importantes de acordo com os protocolos de Doença Falciforme

$12 \mathrm{Na}$ fase da pesquisa de Doutorado (2016), o TCLE foi ampliado para utilização do uso de imagens e vídeos dos participantes do estudo, com autorizações de publicações de entrevistas gravadas durante a pesquisa de campo. A etapa em questão gerou a produção de um vídeo que foi aceito e apresentado no GT de Vídeos Etnográficos no Congresso Internacional de Etnobiologia que ocorreu em Belém (2018). O link do resultado do vídeo é https://www.youtube. com/watch?v=-HMgFwJi7P4\&t=13s. 
do Ministério da Saúde (Brasil 2016b), precedido da autorização para coleta de sangue para exame de DNA (DNA autossômico), utilizado para o teste de ancestralidade.

A segunda etapa constava da entrega dos resultados dos testes genéticos e de outro questionário com perguntas subjetivas sobre a percepção dos resultados dos laudos, cujos grupos foram divididos em ancestralidade "ameríndia”, "europeia" e "africana", de acordo com a maior porcentagem de frequência gênica apresentada por cada interlocutor.

Os resultados demonstraram que a maioria deles apresentou DNA europeu (58,2\%), ameríndio $(21,8 \%)$ e africano (20\%), porém $90 \%$ se autodeclarou negro ou pardo, o que evidencia o alto índice de mistura genética em nossa população. A expressão de surpresa ao receberem esses resultados era visível em seus rostos e falas, visto que comprovavam o contrário de como se autodeclaravam de modo identitário. Esse tipo de resultado contribuiu para uma quebra de paradigmas, visto que a AF é considerada na literatura como uma doença de maior prevalência em populações afrodescendentes, no entanto, os índices de proporções genéticas do grupo estudado confirmam os processos sociohistóricos do Out of África para a Amazônia, a chamada Diáspora Africana, assim como as características regionais de ocupação do território desde a colonização, dados fundamentais para a compreensão da complexidade genética da população local (Almeida 2010, Tales et al. 2017, Silva et al. 2020).

No grupo paraense estudado existe ainda uma variação de $18 \%$ de mulheres que exibem maior quantidade e maior gravidade de sintomas em relação aos homens, $65 \%$ dos participantes vivem na pobreza e tem baixo índice de escolaridade e $72 \%$ afirmam ter sofrido racismo e discriminação ao longo da vida (Silva 2015, Silva 2016, Silva et al. 2018).

As entrevistas foram gravadas em câmeras de celulares ou semiprofissionais, além dos áudios das entrevistas em gravadores de mão, quando o uso da imagem não era autorizado. Ainda assim, cerca de $80 \%$ dos entrevistados autorizaram o uso da imagem para fins científicos e ao longo de nove meses de trabalho de campo, com intervalo de um mês pela espera dos resultados genéticos, foram realizadas 120 entrevistas longas, conseguindo coletar um número significativo de informações sobre $\mathrm{AF}$, com seus respectivos dados clínicos, genéticos e socioculturais fundamentais para a compreensão bioantropológica da AF na Amazônia.

Durante o período em questão, houve a oportunidade de reencontrar os interlocutores algumas vezes no hemocentro, além do momento da entrevista em si, conseguindo manter um contato mais aproximado durante e após a pesquisa, tanto 
via mensagens de WhatsApp como em outras mídias sociais.

Um dos entrevistados faleceu alguns meses após a entrega do resultado de ancestralidade e dois deles foram indicados para o Transplante de Medula Óssea (TMO), único tratamento que consegue curar a AF até o momento, sendo que em 2019 uma participante conseguiu realizar o transplante e o outro ainda aguarda a sua vez. Para a realização de transplante de medula óssea, no caso de pessoas com AF, é necessário que o doador seja $100 \%$ compatível com o receptor, ou seja, deve ocorrer entre irmãos de mesmos pais/ mães ou parentes próximos ${ }^{13}$.

A pesquisa social ainda enfrenta muitos desafios pela frente, mas em 2016, teve-se um marco, com a Resolução 510/2016 de CHS (Brasil 2016a), que é um alicerce inicial de contestação ao padrão biomédico dominante, um passo importante na elaboração das pesquisas na área das CHS, pois considera que a ética é uma construção humana, portanto histórica, social e cultural. Nela, alguns avanços podem ser apontados, pois o documento afiança que "a relação pesquisador-participante se constrói continuamente no processo da pesquisa, podendo ser redefinida a qualquer momento no diálogo entre subjetividades, implicando reflexividade e construção de relações não hierárquicas" (Brasil 2016a: 1) que, em especial, coaduna com o modus operandis da Antropologia/Bioantropologia, que constrói o seu universo de pesquisa no decorrer do trabalho de campo.

\section{CONSIDERAÇÕES FINAIS}

Os percursos apontados são alguns motes de como o bioantropólogo pode usar a pesquisa etnográfica em seu trabalho de campo. Ser filtrado por um Comitê de Ética não é um privilégio, é apenas uma introdução aos desafios do campo, dentre tantas outras que estarão por vir e que talvez trilhem aberturas diversas. Todavia, a forma como o observador da Bioantropologia deve portar-se em seu métier é consideravelmente diferenciado: o ser aceito no grupo acometido por uma enfermidade, a empatia da reciprocidade, o reconhecimento de ritos técnicos e de oralidades peculiares durante os levantamentos, exigem não apenas afinidade, mas documentações, interferências e muitos obstáculos éticos/bioéticos.

O conhecimento e a análise biocultural sobre os interlocutores, as noções sobre sintomas e crises de dor em pesquisas sobre doenças genéticas crônicas e o entendimento dos processos microevolutivos da Anemia

13 http://www.blog.saude.gov.br/index.php/servicos/53389-transplante-de-medula-muda-vida-de-pessoa-com-doencafalciforme. 
Falciforme - ou da hipertensão, diabetes e outras como também de sua família e a sensibilização cronicidades -, são algumas categorias a serem do pesquisador na percepção de como a saúde consideradas. As situações de suscetibilidade e as doenças humanas são representadas biossocial, econômica, étnico-racial, estrutural, em sociedade, permitem inferir que o fazer ética e bioética não apenas do interlocutor, bioantropológico é de uma complexidade que,

afora ser muito instigante, é um grande desafio que deve ser provocado e disseminado.

\section{REFERÊNCIAS}

Almeida, Ivete B. S. 2010. Culturas africanas, culturas diaspóricas: uma reflexão. História e Perspectivas 43: 197-214.

Brasil. 1996. Resolução nº 196, de 10 de outubro de 1996. Diário Oficial da União. Brasília: Conselho Nacional de Saúde/Ministério da Saúde.

Brasil. 2012. Resolução no 466, de 12 de dezembro de 2012. Diário Oficial da União. Brasília: Conselho Nacional/Saúde do Ministério da Saúde.

Brasil. 2016a. Resolução n ${ }^{\circ}$ 510, de 07 de abril de 2016. Diário Oficial da União. Brasília: Conselho Nacional de Saúde/Ministério da Saúde.

Brasil, 2016b. Protocolo clínico e diretrizes terapêuticas doença falciforme: relatório de recomendação. Brasília: CONITEC/Ministério da Saúde.

Brasil. 2020. Comitês de Ética em Pesquisa no Brasil. http://conselho.saude.gov.br/comites-de-eticaem-pesquisa-conep?view=default.

Bezerra, Ivone e Silva, Hilton Pereira. 2009. Tirando do pó: uma introdução metodológica sobre o tratamento de remanescentes ósseos humanos de origem arqueológica. Revista de Arqueologia. 22 (2): 121- 135. https://revista.sabnet.org/index.php/sab/article/view/278/418

Cançado, Rodolfo. 2007. Doenças falciformes. Prática Hospitalar 50:61-64.

Cardoso de Oliveira, Roberto. 2000. O trabalho do antropólogo. São Paulo: UNESP. 
Cardoso, Greice Lemos e Guerreiro, João Farias. 2010. Molecular characterization of sickle cell anemia in the Northern Brazilian State of Pará. American fournal of Human Biology 22:573-577.

Castro, Leonardo. 2008. Pagamento a participantes de pesquisa, in Ética em pesquisa: temas globais. Editado por Diniz, Débora; Sugai, Andrea, Guilhem, Dirce e Squinca, Flávia, pp. 219-252. Brasília: Letras Livres, UnB.

Costa, Sérgio. 2008. O desafio da ética em pesquisa e da bioética, in Ética em pesquisa: temas globais. Editado por Diniz, Débora; Sugai, Andrea, Guilhem, Dirce e Squinca, Flávia, pp. 25-53. Brasília: Letras Livres, UnB.

Da-Glória, Pedro e Piperata, Bárbara. A. 2019. Modos de vida dos ribeirinhos da Amazônia sob uma abordagem biocultural. Ciência e Cultura. 71 (2). http://cienciaecultura.bvs.br/scielo.php?script=sci_ arttext\&pid=S0009-67252019000200014.

Diniz, Débora e Guilhem, Dirce. 2008. O que é bioética. São Paulo: Brasiliense.

Ferreira, Jaqueline e Fleischer, Soraia. Organizadoras. 2014. Etnografias em serviços de saúde. Rio de Janeiro: Garamond.

Folha de São Paulo. 2006. Uso de cobaias humanas no Amapá causa horror, diz senador. https://www1. folha.uol.com.br/folha/ciencia/ult306u14130.shtml

Fonseca, Claudia. 2010. Que ética? Que ciência? Que sociedade? in Ética e regulamentação na pesquisa antropológica. Editado por Fleischer, Soraia e Schuch, Patrice. Brasília: Letras Livres, UnB.

Fry, P. H. et al. 2007. AIDS tem cor ou raça? Interpretação de dados e formulação de políticas de saúde no Brasil. Cadernos de Saúde Pública. 23(3):497-523.

Gamble, Vanessa Northington. 1995. Making a place for ourselves: The Black Hospital Movement, 1920=1945. Oxford: University Press.

Gaspar-Neto, Verlan Valle. 2012. A outra face do crânio: Antropologia biológica no Brasil hoje. Tese de doutorado, Programa de Pós-Graduação em Antropologia, Universidade Federal Fluminense. http:// ppgantropologia.sites.uff.br/wp-content/uploads/sites/16/2016/07/VERLAN-VALLE-GASPAR-NETO.pAF.

Geertz, Clifford. 2000. Do ponto de vista dos "nativos": a natureza do entendimento antropológico. pp. 107-85. Petrópolis: Vozes. 
Giumbelli, E. 2020. Para além do "trabalho de campo": reflexões supostamente malinowskianas. RBCS. 17 (48): 91-107. https://www.scielo.br/scielo.php?pid=S0102-69092002000100007\&script=sci abstract\&tlng=pt

Guerreiro, João Farias; Figueiredo, Mauro Silvério e Zago, M. A. 1994. Beta-globin gene cluster haplotypes of Amerindian populations from the Brazilian Amazon Region. Human Heredity. 44:142-149.

Guerreiro, João Farias et al. 1999. Genetical-demographic data from two Amazonian populations composed of descendants of African slaves: Pacoval and Curiau. Genetics and Molecular Biology. 22(2): 163-16.

Guerriero, Iara Coelho Zito e Bosi, Maria Lúcia Magalhães. 2015. Ética em pesquisa na dinâmica do campo científico: desafios na construção de diretrizes para ciências humanas e sociais. Ciência \& Saúde Coletiva. 20(9): 2615-2624.

Holland, Brynn. 2017. The 'Father of Modern Gynecology' Performed Shocking Experiments on Slaves. 2017. https://www.history.com/news/the-father-of-modern-gynecology-performed-shocking-experimentson-slaves

Laguardia, Josué. 2002. Raças e doenças: uma relação delicada. PHYSIS: Revista de Saúde Coletiva. 12(2):409-422.

Laguardia, Josué. 2006. No fio da navalha: anemia falciforme, raça e as implicações no cuidado à saúde. Estudos Feministas. 14(1): 243-262.

Laplantine, François. 2004. Antropologia da doença. São Paulo: Martins Fontes. 274 p.

Luna, Florencia. 2008. Consentimento livre e esclarecido: ainda uma ferramenta útil na ética em pesquisa, in Ética em pesquisa: temas globais. Editado por Diniz, Débora; Sugai, Andrea, Guilhem, Dirce e Squinca, Flávia, pp. 154-186. Brasília: Letras Livres, UnB.

Luz, Ilana Martins. 2014. A criminalização dos ensaios clínicos com seres humanos: carência e dignidade de tutela ou expansionismo penal? Revista Direito UNIFACS - Debate Virtual. 176.

Kottow, Miguel. 2008. História da ética em pesquisa com seres humanos, in Ética em pesquisa: temas globais. Editado por Diniz, Débora; Sugai, Andrea, Guilhem, Dirce e Squinca, Flávia, pp. 53-83. Brasília: Letras Livres, UnB. 
Martínez, Gabriela Rueda. 2014. Uma visão bioética da regulamentação colombiana sobre pesquisas com seres humanos e normas de publicação. Dissertação de mestrado, PPGB, Universidade de Brasília, Brasília.

Minayo, Maria Cecília Souza. 2000. O desafio do conhecimento: pesquisa qualitativa em saúde. Rio de Janeiro: Hucitec; São Paulo: Abrasco.

Morais, Inês Motta. 2010. Vulnerabilidade do doente versus autonomia individual. Revista Brasileira de Saúde Materno Infantil. 10 (Supl. 2): S331-S336.

Munanga, Kabengele. 2004. A difícil tarefa de definir quem é negro no Brasil. Estudos Avançados. 18(50):51-66.

Naoum, Paulo C. 2000a. Interferentes eritrocitários e ambientais na anemia falciforme. Revista Brasileira de Hematologia e Hemoterapia. 22(1):05-22.

Naoum, Paulo C. 2000b. Prevalência e controle da hemoglobina S. Revista Brasileira de Hematologia e Hemoterapia. 22 (Supl. 2):342-148.

Naoum, Paulo C. 2011. Sickle cell disease: from the beginning until it was recognized as a public health disease. Revista Brasileira de Hematologia e Hemoterapia. 33(1): 7-9.

Oliveira, Luís Roberto Cardoso. 2010. A antropologia e seus compromissos ou responsabilidades éticas, in Ética e regulamentação na pesquisa antropológica. Editado por Fleischer, Soraia e Schuch, Patrice, pp. 25-38. Brasília: Letras Livres, UnB.

Peirano, Mariza. 1995. Uma antropologia no plural: três experiências contemporâneas. Brasília: UnB.

Peirano, Mariza. 2008. Etnografia, ou a teoria vivida. Ponto Urbe. 2: 2.0. 10.4000/pontourbe.1890.

Rogers, Wendy e Ballantyne, Angela. 2008. Populações especiais: vulnerabilidade e proteção, in Ética em pesquisa: temas globais. Editado por Diniz, Débora; Sugai, Andrea, Guilhem, Dirce e Squinca, Flávia, pp. 123-151. Brasília: Letras Livres, UnB.

Santos, Rafael Cleison Santos e Santos, Elinaldo Conceição. 2011. Malária: cobaias humanas no Amapá. Estação Científica (UNIFAP). 1 (2): 143-150. 
Santos, Ricardo Ventura e Maio, Marcos Chor. 2005. Antropologia, raça e os dilemas das identidades na era da genômica. História, Ciências, Saúde Manguinhos. 12(2): 447-68.

Silva, Hilton Pereira. 2009. Variabilidade, raça e racismo: conversando sobre a diversidade biocultural humana, in Diversidade; Educação e Direitos: Etnologia Indígena. Editado por Beltrão, Jane Felipe e Mastop-Lima, Luiza de Nazaré, pp. 51-59. Belém: IEMCI-UFPA.

Silva, Ariana Kelly Leandra. 2012. Doença como experiência: Relações entre vulnerabilidade social e corpo doente enquanto fenômeno biocultural no Estado do Pará. Dissertação de mestrado, Programa de Pós-Graduação em Antropologia, Universidade Federal do Pará, Belém.

Silva, Ariana Kelly Leandra e Silva, Hilton Pereira. 2013. Anemia Falciforme como experiência: as relações entre vulnerabilidade social e corpo doente enquanto fenômeno biocultural no estado do Pará. Amazônica, Revista de Antropologia. 5 (1):10-36.

Silva, Ariana Kelly Leandra. 2015. O contexto epidemiológico e biossocial da doença falciforme no estado do Pará, Amazônia, Brasil. Revista da ABPN. 7 (16):103-127.

Silva, Ariana Kelly Leandra. 2016. Doença falciforme, preconceito linguístico e sociorracial: a desinformação como determinante social da saúde no estado do Pará. Amazônica, Revista de Antropologia. 8 (2): 518-539.

Silva, Ariana Kelly Leandra et al. 2018. Renda e cor de pessoas com anemia falciforme atendidas na Fundação Hemopa, Pará, Amazônia, Brasil: realidade e perspectivas. Revista da ABPN. 10 (24): 366-391.

Teles, Annyelle Figueredo; Silva, Amanda Cordeiro da, Silva, Luciana da Costa e Souza, Lidiane Oliveira de. 2017. Hemoglobinas de origem africana em comunidades quilombolas do estado do Tocantins, Brasil. Revista Pan-Amazônica de Saúde. 8 (1): 39-46.

Uriarte, Urpi Montoya. 2012. O que é fazer etnografia para os antropólogos. Ponto Urbe. 11. em: https:// journals.openedition.org/pontourbe/300

Valêncio, Luís Felipe Siqueira e Domingos, Claudia Regina Bonini. 2016. O processo de consentimento livre e esclarecido nas pesquisas em doença falciforme. Revista Bioética. 24 (3): 469-477.

Young, Michael W. 2004. Malinowski: Odyssey of an anthropologist, 1884-1920. Yale: University Press. 
